\title{
Economic Integration in Latin America
}

Hem C. Basnet

Chadron State College, Chadron, U.S.A.

Subhash C. Sharma

Southern Illinois University, Carbondale, U.S.A.

\begin{abstract}
This study examines the feasibility of economic integration in Latin America. We analyze the existence of the long-term and short-term common movements among key macro variables - real GDP, intra-regional trade, private investment and consumption - in the seven largest economies in Latin America - Argentina, Brazil, Chile, Colombia, Mexico, Peru and Venezuela. The joint behavior of the long term trends and the joint response to transitory shocks suggest a significant degree of economic synchronization among these countries. Our results reveal that the economic fluctuations in these countries follow a similar pattern in terms of duration, intensity, response, and timing both in the long run and in the short run. The findings suggest that the group of seven economies in Latin America can lead the path of integration in the region more smoothly as macroeconomic conditions are favorable for them to do so.
\end{abstract}

JEL Classifications: E32, F15, F42

Key words: Common Trends, Common Cycles, Economic Integration, Synchronization

\footnotetext{
* Corresponding Author: Hem C. Basnet; Department of Business, Chadron State College, 1000 Main Street, Chadron, NE 69337, U. S. A.; Tel: +1 3084326476, Fax: +1 3084326430, E-mail: hbasnet@csc.edu.

Co-Author: Subhash C. Sharma; Department of Economics, Southern Illinois University, 1000 Faner Drive, Carbondale, IL 62901, U. S. A.; Tel: +1 6184535082, Fax: +1 6184532717, E-mail: sharma@siu.edu. 


\section{Introduction}

Regional economic integration results from agreements between groups of nations to reduce and eventually to eliminate barriers to the movement of goods, services and factors of productions among member nations. Until the early twentieth century, most countries employed various trade barriers in order to protect domestic industries. It was a common belief that the protection of domestic industries would create more employment and help the economy to grow. Over a period of time, policy makers realized that the free movement of goods, services, and the factors of production can lead to more efficiency in both production and consumption, which accelerates the pace of economic growth. The formation of the European Common Market, which was ultimately transformed into the European Union is an outcome of this realization. On the other side of the Atlantic, the North American Free Trade Agreement (NAFTA) was formed with Canada, USA, and Mexico as member nations with similar objectives. The process of regional economic integration is also under way in other parts of the world. The Latin American Free Trade Agreement (LAFTA), the Greater Arab Free Trade Area (GAFTA), and the Economic Community of West African States (ECOWAS), just to name a few, are some of the active regional blocs, seeking greater and more viable economic integration in their respective regions.

As mentioned above, regional economic integration stimulates economic growth through additional gains from trade and mobility of factors of production among member countries. Economic interdependence also results in greater cooperation, a larger market in the region, and an increase in bargaining power in the global economy. Therefore, many countries around the world are trying to follow the integrationist footsteps of European integration. The core lesson learned from the European Union is that despite many differences with respect to goals, and policies among countries in a region, economic integration among those countries can take place and succeed.

The concept of regional integration in the Latin American context dates back to 1960 when the Latin American Free Trade Association (LAFTA) ${ }^{1}$ was created. The goal of LAFTA was to create a common market in Latin America and it was perceived as a first step towards economic integration in Latin America. Many Latin

\footnotetext{
'The initial signatories of the LAFTA charter were Argentine, Brazil, Chile, Mexico, Paraguay, Peru, and Uruguay. By 1970, LAFTA had expanded to include four more Latin American nations-Bolivia, Colombia, Ecuador, and Venezuela. In 1980, LAFTA was reorganized into the Latin American Integration Association (ALADI).
} 
American economists took it as a promising vehicle for enhancing economic and social development in their respective countries (Rosenthal, 1985). This initial enthusiasm, however, gradually faded away and a general air of pessimism regarding integration spreads. Over the course of the past three and half decades, the process of achieving deeper economic integration has suffered numerous setbacks. Frequent abrupt political changes have been a deterrent to economic cooperation. During the 1960s, LAFTA was disrupted by military coups in Argentina and Brazil. ${ }^{2}$ Due to this, it is believed that integration could not make any progress and obviously the region could not reap the benefits of greater regional economic integration. In addition to that, Latin American countries were left out of this line of research mainly due to a lack of stability and data (Fullerton and Araki, 1996; Mena, 1995). However, the movement towards deeper Latin American economic integration is gaining momentum. The formulation of the Common Market of the South or MERCOSUR - the largest regional trade area signed in 1991 between Argentina, Brazil, Paraguay, Uruguay (and more recently Venezuela), with Bolivia, Chili, Peru, Colombia, and Ecuador as associates - is seen as evidence of a gain in momentum. As a matter of fact, the 1990s was characterized by intense parley of regional trade agreements in Latin America. More than 14 agreements ${ }^{3}$ - free trade areas or custom unions - since 1990 have been made in the region. Economic integration refers to any type of arrangement between countries to coordinate their trade, fiscal, and monetary policies. There are different degrees of economic integration that range from low levels of integration such as preferential trade agreements (PTA) to economic unions of the European style. The first step of integration begins with a PTA which consists of selective tariff reduction with regard to certain countries and specific product categories. In fact, a PTA is not allowed among World Trade Organization (WTO) member countries. Countries are said to be more integrated if they coordinate to create a Free Trade Area (FTA). An FTA is an agreement to eliminate tariffs among a group of countries but maintain their own external tariffs on imports from the rest of the world. The intensity of economic integration increases when a group of countries plunges into a customs union and thereby a common market. Under a customs union a group of countries agrees to eliminate tariffs among themselves and set a common

\footnotetext{
${ }^{2}$ There were six military takeovers in Argentine during the $20^{\text {th }}$ century, three of them took place (in 1962, 1966 and 1976) after the inception of the LAFTA. Likewise, the region's largest economy — Brazil - also suffered from the authoritarian military dictatorship in the infant stage of LAFTA. The Brazilian military overthrew the democratically elected civilian government and ruled the country under the authoritarian dictatorship from 1964 to 1985 . Those events, in leading economies, resulted in doubts about the prospect of LAFTA's future as economic integration very much less depends on the peoples' popular support and political consensus.

${ }^{3}$ For details see: Allegret and Sand-Zantman (2009). Also, see Bond (1978) for the early efforts Latin American countries made towards regionalism.
} 
external tariff on imports from the rest of the world. A common market establishes the free mobility of capital and labor in addition to having free trade in goods and services and setting a common tariff among member countries. An economic union is the highest level of economic integration among a group of countries in which goods and services, labor, and capital move freely and also involves the transfer of some authority to a supranational body that controls some fiscal spending among the member countries. This paper aims to make the case for economic union rather than a low level of economic integration, which in most of the cases already exists in one way or another. In order to achieve a continent-wide economic union careful and rigorous investigation about macroeconomic variables must be conducted to weigh the costs and benefits of forming an economic union (Schiff and Winters, 1998). However, Latin America seems to be behind in its endeavor to evaluate the economic synchronization of macroeconomic variables in the region.

This study analyzes the feasibility of an economic union in Latin America or how feasible it is to imitate European-style integration model in Latin America. According to conventional literature a greater degree of macroeconomic synchronization or business cycle co-movement is considered a necessary condition for the harmonization of economic policies and institutions among countries involved in an economic integration process (Christodoulakis, Dimelis, and Kollintzas, 1995; Fiorito and Kollintzas, 1994). If business cycle fluctuations are synchronized, harmonized policies to cope with such cycles across countries can be effective (Sato and Zhang, 2006). The argument behind this logic is that if the impact of a shock across countries is not symmetric then harmonized monetary and fiscal policies could be detrimental. According to Mundell (1961), the overall degree of economic integration can be judged by looking at the integration of product and factor markets between the joining countries and the currency area. Existing studies (e.g. see Bayoumi and Eichengreen, 1994; Bayoumi, Eichengreen, and Mauro, 2000; Berg et al., 2002; De Grauwe and Zhang, 2006) suggest that for economic integration to take root i) the degree of macroeconomic synchronization between the prospective members of a union should be high ii) the extent to which the economies of prospective members are subject to asymmetric shocks should be low, and iii) the degree of flexibility in the labor markets should be similar.

In order to explore the feasibility of economic integration we analyze the long-term trends and the short - term cycles of key macroeconomic variables - gross domestic product, intra-Latin American trade flows, private consumption, and investment. In this study, real GDP and intra - regional trade capture the integration of product markets 
and private investment represents the factor market (i.e. capital). Additionally, we further investigate the trend-cycle behavior of consumption. Despite our efforts to be as thorough and comprehensive in analyzing the case as possible the paper does not intend to analyze the common trend and cycles of the labor market. We have chosen the seven leading economies (Argentina, Brazil, Chile, Colombia, Mexico, Peru, and Venezuela) of Latin America. These seven countries account for more than $90 \%$ of the continent's GDP and about 93\% of its population in 2008. Their trade share of GDP in the region is also significant and growing (Table 1). All these countries except Mexico conduct average of about one fourth of their trade share within the region. The lower share of Mexican trade can be attributed to its strong commercial ties with its NAFTA partners - USA and Canada. Our rationale for this choice is that if the leading economies share common trends and cycles in their key macro variables then these countries constitute a core group and can be considered good candidates for an economic union. Peripheral countries - closely tied to these economies, account for a small portion of regional market - may be receptive to joining, which may result in the complete integration of the entire continent.

Table 1. Share of real GDP and Intra-regional trade in the Latin American region

\begin{tabular}{|cccccccc|}
\hline \multicolumn{7}{c}{ Percent of real GDP } \\
\hline $1980 \sim 1984$ & 15.07 & 31.24 & 2.05 & 4.03 & 27.43 & 2.98 & 6.43 \\
$1985 \sim 1989$ & 13.49 & 34.09 & 2.29 & 4.38 & 25.93 & 2.90 & 6.21 \\
$1990 \sim 1994$ & 13.60 & 31.71 & 2.93 & 4.78 & 27.01 & 2.33 & 6.45 \\
$1995 \sim 1999$ & 14.34 & 31.42 & 3.55 & 4.80 & 25.77 & 2.59 & 6.00 \\
$2000 \sim 2004$ & 12.84 & 32.02 & 3.85 & 4.75 & 28.15 & 2.69 & 5.44 \\
$2005 \sim 2008$ & 14.17 & 31.71 & 3.94 & 5.01 & 26.90 & 2.97 & 6.04 \\
& & & Percent of intra-regional trade & & \\
$1980 \sim 1984$ & 22.29 & 13.76 & 21.34 & 19.19 & 6.24 & 13.95 & 27.52 \\
$1985 \sim 1989$ & 26.36 & 12.49 & 19.96 & 18.40 & 5.44 & 18.63 & 18.19 \\
$1990 \sim 1994$ & 33.68 & 19.28 & 20.67 & 24.39 & 5.76 & 26.72 & 29.28 \\
$1995 \sim 1999$ & 38.49 & 23.29 & 24.22 & 26.56 & 4.10 & 25.13 & 27.65 \\
$2000 \sim 2004$ & 41.04 & 20.79 & 27.22 & 29.73 & 4.13 & 25.82 & 32.00 \\
$2005 \sim 2008$ & 41.69 & 22.68 & 23.31 & 32.73 & 5.84 & 28.18 & 29.09 \\
\hline
\end{tabular}

(Source) World Development Indicators (2009) and Direction of trade statistics year book. 
Unlike the case of European integration, few studies have investigated the prospect of economic union in Latin America. Past studies have examined economic integration based on observed similarities of its economies and correlation analysis of its business cycles. The problem with these methodologies is that the degree of correlation between shocks does not accurately follow short-run output co-movements (Sato et al., 2007). Hence, we complement our analysis by testing long and short-run co-movements in macroeconomic indicators. For an integration process to be viable, it is essential to have both long-run synchronous output co-movements and short-run common business cycles to minimize the need for country-specific policies that may hinder the stability of the union (Abu-Aarn and Abu-Bader, 2008). To the best of our knowledge, very few studies, most notably Engle and Issler (1993), have analyzed the degree of macroeconomic synchronization between Argentina, Brazil, and Mexico by employing the common trends and common cycles methodology.

The rest of the paper is organized as follows. The next section presents a review of past studies that deal with the topic of synchronous movement between macroeconomic variables and economic integration. Section III describes the methodology used to analyze business cycle synchronization and integration. In section IV, empirical results are reported. Finally, we state concluding remarks.

\section{Literature Review}

Business cycles co-movements between the economies of Latin American countries have been examined from a variety of perspectives. For instance, Engle and Issler (1993) investigated the degree of short and long run comovements in GDP per capita of three Latin American countries (Argentina, Brazil, and Mexico) using the common trends and common cycles methodology and documented that while Argentine and Brazil share both long and short run co-movement, Mexico does not have similar trend or cyclical behavior with either of those countries. Similarly, Arnaudo and Jacobo (1997) considered four Latin American countries - Argentina, Brazil, Paraguay, and Uruguay — and noted that there is significant synchronization only between Argentina and Brazil. In contrast, in a study of eight Latin American countries and the United States, Mejia-Reyes (1999) found no evidence of a Latin American common 
cycle but the author found significant synchronization between several countries ${ }^{4}$ in a bivariate context. Jacobo (2002) studied the macroeconomic behavior of six Latin American countries, i.e. Argentina, Bolivia, Brazil, Chile, Paraguay, and Uruguay for the period of 1970 1997 and found weak economic linkage between these countries. Hallwood et al. (2006) examined the possibility of a Latin American monetary union between Argentina, Brazil, Chile, Uruguay, and Venezuela or a monetary union with the USA through official dollarization. Their empirical findings do not support the formation of a monetary union between Latin American countries or with the USA through dollarization due to asymmetric macroeconomic shocks. Fiess (2007) measured the degree of business cycle synchronization between Central America ${ }^{5}$ and the United States and observed that business cycle synchronization within Central American countries is quite low. This finding does not support any macroeconomic coordination within Central America. In a recently published paper, Allegret and Sand-Zantman (2009) studied the feasibility of a monetary union between five Latin American Countries - Argentina, Brazil, Chile, Mexico, and Uruguay. In doing so, they have investigated whether this set of countries is characterized by business cycle synchronization. Based on results obtained from the VAR model the study does not support a monetary union in Latin America even though Uruguayan economic activity depends mainly on Argentinian and Brazilian business cycles. Caceres (2011), on the other hand, provides evidence of interdependence in the labor markets of Mercosur countries and supports the idea of deeper integration for the benefit of lowering the unemployment rates of the member countries.

A number of researchers, e.g. Sharma (1997); Sato and Zhang (2006); Abu-Qarn and Abu-Bader (2008); and Adom et al. (2010) among others have used the common trends and the common cycles methodology to examine the feasibility of economic union in a number of countries. The main premise of these studies is that if a group of countries share common long term trends and short term cycles in their macroeconomic variables then these countries are considered good candidates for economic union. In a recent paper, Adom et al. (2010) examine the feasibility of an African economic union by applying the common trends and common cycles methodology. They find the presence of both long term trends and short term cycles among the key macro variables of the eight largest African economies and hence their results suggest that some preconditions

\footnotetext{
${ }^{4}$ Argentina-Brazil, Argentina-Peru, Bolivia-Venezuela, Brazil-Peru, Chile-United States, Argentina-Bolivia, Mexico-Venezuela, and Brazil-United States).

${ }^{5}$ Costa Rica, El Salvador, Guatemala, Honduras, Nicaragua, Panama.
} 
for the successful integration of Africa are currently in place.

After the inception of the North American Free Trade Agreement (NAFTA), several studies (e.g. see Chiquiar and Ramos-Francia, 2005) have examined business cycle synchronization in North America. For instance, Castillo-Ponce, Acosta, and Jesus (2008) identify the existence of common trends and common cycles in the gross domestic products of Canada, Mexico, and the United States. Their pre-and postNAFTA analysis suggests that North American economies were highly synchronized upon the signing of the NAFTA agreement. By implementing the common cycles methodology, Hernandez (2004) shows that the economies of two North American countries - Mexico and US - share a common trend and also exhibit a similar response to transitory shocks. From a monetary union perspective, Sato and Zhang (2006) noted the feasibility of a monetary union in East Asia as the real output shortrun dynamics of the countries in that region are correlated and they also share longrun output movements. By studying long run trends and short run cycles in the macro variables of the Gulf Cooperation Council (GCC) countries, Abu-Qarn and Abu-Bader (2008) examine whether the GCC countries are ready to form a viable monetary union in that region. Their findings do not support the readiness of the GCC countries to establish a viable currency union.

\section{Data and Methodology}

Yearly data on real gross domestic product $(R G D P)$, intra-regional trade (TRADE), investment (INVEST.) and consumption (CONS.) are used for the seven largest Latin American countries-Argentina, Brazil, Chile, Colombia, Mexico, Peru, and Venezuela. Data is obtained from World Development Indicators (WDI-2009) and various issues of the Direction of Trade Statistics year book. Since we are investigating the feasibility of economic union in Latin America, we first investigate trade intensity among the sample countries within the region. For this, intra-regional trade data is used rather than trade flows, measured by the sum of imports and exports. Intra-regional trade only covers the sum of exports plus imports from the Latin American countries under consideration. The time span for intra- regional trade ranges from 1978 to 2008, whereas for the rest of the variables it ranges from 1960 to 2008. All data are in constant 2000 US dollars. In accordance with the literature, all the series are transformed into 
their logarithmic forms. During the time span considered in this study, some unusual behaviors in Argentine real GDP are noticed. For instance, the real GDP growth of Argentina plummeted sharply from $8.11 \%$ in 1997 to $-10.98 \%$ in 2003 . Thus, following the standard practice in the literature (see Sylwester, 2005) we smoothed out the real GDP data for Argentina for the years 2001, 2002, and 2003. These three years' data are replaced by the average of year 2000 and 2004. The same smoothing procedure is also applied to consumption for the same time periods. For the rest of the countries, none of the variables have been smoothed out. ${ }^{6}$

\section{A. Methodology}

First, all the variables are tested for stationarity and their order of integration is determined. We employ the Dickey-Fuller test, the Augmented Dickey-Fuller test, the Phillips-Perron (PP) tests, and the KPSS [(Kwiatkowski, Phillips, Schmidt, and Shin (1992)] test for unit roots in each of the series. Next, the maximum likelihood based Johansen (1988) and Johansen and Juselius (1990) cointegration tests are used to test for the long-run relationship among the variables in the following model:

$$
y_{t}=\left(y_{t}^{A r g}, y_{t}^{B r l}, y_{t}^{C h l}, y_{t}^{C o l}, y_{t}^{M e x}, y_{t}^{\text {Per }}, y_{t}^{\text {Ven }}\right)^{\prime}
$$

where, $y_{t}$ is a $(7 \times 1)$ vector of either real GDPs, intra-regional trade, investment, or consumption of the seven countries under investigation. Next, each variable is tested for its significance by using the likelihood ratio (LR) test, i.e., the hypothesis $\mathrm{H}_{0}: \beta_{k}=0$ where $k=1,2, \ldots 7$.

If the variables are cointegrated then the short term cycles and the long term trend components of the series are recovered by using the methodology purposed by Vahid and Engle (1993). According to Vahid and Engle (1993), this methodology tests the significance of the canonical correlations between $\Delta y_{t}$ and $W=\left(\beta^{\prime} y_{t-1}, \Delta y_{t-1}, \Delta y_{t-2}, \ldots, \Delta y_{t-p+1}\right)$. They point out that given $r$ linearly independent cointegrating vectors, if a series $y_{t}$ has common cycles there at most, exist $s=(n-r)$ cofeature vectors that eliminate common cycles (see Vahid and Engle 1993, pp. 345). To test for the significance of canonical correlations between two sets of variables,

\footnotetext{
${ }^{6}$ Since these three years do not represent the normal economic situation in Argentina and are considered outliers. Retaining those outliers in the analysis would distort the results.
} 
following Engle and Issler (1993) we use the F-test approximation proposed by Rao (1973). Engle and Issler note that the F-statistics has higher power than the $\chi^{2}$ test proposed by them. Note that the F-statistics tests the null hypothesis that the dimension of the cofeature space is at least $s$. If there exists $s$ independent cofeature vectors then there are $(n-s)$ common cycles. A dimension of $(n \times s)$ matrix $\tilde{\gamma}$ and of $(n \times r)$ matrix $\gamma$ are referred to as the cofeature and cointegrating vectors, respectively. When $r+s=n$, Vahid and Engle (1993) decompose the permanent (trend) and the transitory (cycle) components of each series. In this case $($ i.e $r+s=n)$ there will be an $(n \times n)$ matrix $\mathrm{A}=\left(\begin{array}{l}\tilde{\gamma}^{\prime} \\ \gamma^{\prime}\end{array}\right)$ with full rank and hence it will have $A^{-1}$. We can proceed to decompose trend and cycle by partitioning the columns of $A^{-1}$ such as $A^{-1}=\left(\tilde{\gamma}^{-} \mid \gamma^{-}\right)$. Finally we recover the trend and cyclical components in the following way:

$$
\begin{array}{r}
y_{t}=\left(A^{-1} A\right) y_{t}=\tilde{\gamma}^{-} \tilde{\gamma}^{\prime} y_{t}+\gamma^{-} \gamma^{\prime} y_{t} \\
=\text { Trend components + Cycle components }
\end{array}
$$

Equation (2) is used to decompose a set of seven series into their trend-cyclical components. The first term represents only the trend component since $\tilde{\gamma}^{-} \tilde{\gamma}^{\prime} y_{t}$ is a random walk and is free from any cycle. The second part is characterized by cyclical components as $\gamma^{-} \tilde{\gamma}^{\prime} y_{t}$ is serially correlated and $\mathrm{I}(0)$.

\section{Empirical Results}

The unit root test statistics for the log first difference of each series are reported in Table 2. To save space, the unit root test statistics for log level are not reported. Based on the results in Table 2, we conclude that all series are first-difference stationary. The sequential likelihood ratio tests suggest that the optimal lag length for the cointegrating model is one for real GDP and intra-regional trade, and two for the investment and consumption models. 
Table 2. Unit Roots Test

(Log, first difference)

\begin{tabular}{|c|c|c|c|c|c|c|c|c|c|c|c|}
\hline \multirow{2}{*}{ Variable } & \multirow{2}{*}{ Country } & \multicolumn{2}{|c|}{ ADF Test } & \multicolumn{2}{|c|}{ DF Test } & \multicolumn{5}{|c|}{ Phillips-Perron Test } & \multirow{2}{*}{$\begin{array}{l}\text { KPSS } \\
\text { Test }\end{array}$} \\
\hline & & $t_{\mu}$ & $t_{\tau}$ & $t_{\alpha^{*}}$ & $t_{\alpha} \sim$ & $Z\left(\Phi_{l}\right)$ & $Z\left(\Phi_{2}\right)$ & $Z\left(\Phi_{3}\right)$ & $Z\left(\tau_{a^{*}}\right)$ & $Z\left(\tau_{\alpha \sim}\right)$ & \\
\hline \multirow{7}{*}{$R G D P$} & Argentina & $-5.716^{*}$ & $-5.670 *$ & $-5.78^{*}$ & $-5.72 *$ & $16.14^{*}$ & $9.74 *$ & $14.61^{*}$ & $-5.85^{*}$ & $-5.86^{*}$ & $0.10^{*}$ \\
\hline & Brazil & $-4.033^{*}$ & $-4.227^{*}$ & $-3.93 *$ & $-4.17 *$ & $9.48 *$ & $6.16^{* *}$ & $9.21 *$ & $-4.15^{*}$ & $-4.46^{*}$ & $0.40^{*}$ \\
\hline & Chile & $-4.966^{*}$ & $-4.992 *$ & $-5.06^{*}$ & $-5.04 *$ & $8970.2 *$ & $8.02 *$ & $12.02 *$ & $-5.11 *$ & $-5.14^{*}$ & $0.17^{*}$ \\
\hline & Colombia & $-4.415^{*}$ & $-4.651^{*}$ & $-4.23 *$ & $-4.69 *$ & $9.32 *$ & $7.40^{*}$ & $11.07^{*}$ & $-4.44 *$ & $-4.92 *$ & $0.28 *$ \\
\hline & Mexico & $-4.564 *$ & $-5.326^{*}$ & $-4.38^{*}$ & $-5.27 *$ & $9.54 *$ & $8.97 *$ & $13.44 *$ & $-4.50 * *$ & $-5.42 *$ & $0.53 *$ \\
\hline & Peru & $-4.261^{*}$ & $-4.191 *$ & $-4.29 *$ & $-4.22 *$ & $8.28^{*}$ & $6.96^{*}$ & 2.41 & $-4.21 *$ & $-4.16^{*}$ & $0.23 *$ \\
\hline & Venezuela & $-5.596^{*}$ & $-5.552 *$ & $-5.61^{*}$ & $-5.58 *$ & $15.42 *$ & $10.10^{*}$ & $15.15^{*}$ & $-5.71 *$ & $-5.74 *$ & $0.16^{*}$ \\
\hline \multirow{7}{*}{ TRADE } & Argentina & $-4.240 *$ & $-4.399 *$ & $-4.51 *$ & $-4.58 *$ & $12.42 *$ & $7.44^{*}$ & $11.12 *$ & $-4.75^{*}$ & $-4.87^{*}$ & $0.10^{*}$ \\
\hline & Brazil & $-4.829 *$ & $-5.043^{*}$ & $-5.20 *$ & $-5.29 *$ & $16.88^{*}$ & $9.67 *$ & $14.48^{*}$ & $-5.39 *$ & $-5.56^{*}$ & $0.11^{*}$ \\
\hline & Chile & $-3.655^{*}$ & $-4.202 *$ & $-3.81 *$ & $-4.17 *$ & $15.14^{*}$ & $6.06^{* * *}$ & $9.07 *$ & $-4.06^{*}$ & $-4.43 *$ & $0.22 *$ \\
\hline & Colombia & $-5.035^{*}$ & $-5.239 *$ & $-5.41^{*}$ & $-5.46^{*}$ & $14.66^{*}$ & $10.06^{*}$ & $15.07 *$ & $-5.60 *$ & $5.77^{*}$ & $0.14^{*}$ \\
\hline & Mexico & $-4.173 *$ & $-4.286^{*}$ & $-4.05^{*}$ & $-3.97 *$ & $1796.1^{*}$ & $4.85 * *$ & $7.23 * *$ & $-4.12 *$ & $-4.12 *$ & $0.07 *$ \\
\hline & Peru & $-6.108^{*}$ & $-6.516^{*}$ & $-6.88^{*}$ & $-7.05^{*}$ & $46.61^{*}$ & $18.97 *$ & $28.17 *$ & $-6.94 *$ & $-7.59 *$ & $0.10^{*}$ \\
\hline & Venezuela & $-4.837^{*}$ & $-5.062 *$ & $-4.90 *$ & $-5.06^{*}$ & $12.00^{*}$ & $8.73^{*}$ & $13.08^{*}$ & $-5.07^{*}$ & $-5.46^{*}$ & $0.18^{*}$ \\
\hline \multirow{7}{*}{ INVEST. } & Argentina & $-5.425^{*}$ & $-5.425^{*}$ & $-5.50 *$ & $-5.49 *$ & $15.56^{*}$ & $9.52 *$ & $14.28^{*}$ & $-5.53^{*}$ & $-5.59^{*}$ & $0.09 *$ \\
\hline & Brazil & $-5.816^{*}$ & $-5.788^{*}$ & $-5.81 *$ & $-5.80 *$ & $16.69^{*}$ & $10.89 *$ & $16.35^{*}$ & $-5.91 *$ & $-5.96 *$ & $0.12^{*}$ \\
\hline & Chile & $-7.268^{*}$ & $-7.331 *$ & $-7.44^{*}$ & $-7.47 *$ & $97.09^{*}$ & $20.96^{*}$ & $31.45^{*}$ & $-7.89 *$ & $-8.23 *$ & $0.30^{*}$ \\
\hline & Colombia & $-5.529 *$ & $-5.484 *$ & $-5.71^{*}$ & $-5.65^{*}$ & $16.26^{*}$ & $10.57 *$ & $15.86^{*}$ & $-5.85 * *$ & $-5.86^{*}$ & $0.05^{*}$ \\
\hline & Mexico & $-6.478^{*}$ & $-6.481 *$ & $-6.43 *$ & $-6.46^{*}$ & $53.49^{*}$ & $13.91 *$ & $20.86^{*}$ & $-6.59^{*}$ & $6.73 *$ & $0.15^{*}$ \\
\hline & Peru & $-5.800 *$ & $-5.888 *$ & $-5.45^{*}$ & $-5.48 *$ & $14.09 *$ & $9.28 *$ & $13.91 *$ & $-5.45^{*}$ & $-5.56^{*}$ & $0.29 *$ \\
\hline & Venezuela & $-7.055^{*}$ & $-6.993 *$ & $-7.14^{*}$ & $-7.07 *$ & $32.84^{*}$ & $18.38^{*}$ & $27.58^{*}$ & $-7.71^{*}$ & $-7.73 *$ & $0.19 *$ \\
\hline \multirow{7}{*}{ CONS. } & Argentina & $-5.785^{*}$ & $-5.722 *$ & $-5.82 *$ & $-5.76^{*}$ & $16.37^{*}$ & $10.54^{*}$ & $15.77 *$ & $-5.89 *$ & $-5.90 *$ & $0.31^{*}$ \\
\hline & Brazil & $-5.290 *$ & $-5.541 *$ & $-5.21 *$ & $-5.56^{*}$ & $14.96^{*}$ & $10.82 *$ & $16.22 *$ & $-5.54 *$ & $-5.89 *$ & $0.38^{*}$ \\
\hline & Chile & $-7.164 *$ & $-7.095^{*}$ & $-7.24 *$ & $-7.16^{*}$ & $27.71 * *$ & $17.21 *$ & $25.79 *$ & $-7.42 *$ & $-7.42 *$ & $0.06^{*}$ \\
\hline & Colombia & $-4.936^{*}$ & $-4.951 *$ & $-4.73 *$ & $-4.82 *$ & $12.49^{*}$ & $6.85^{*}$ & $10.21^{*}$ & $-4.64 *$ & $-4.78^{*}$ & $0.12 *$ \\
\hline & Mexico & $-4.390 *$ & $-4.894 *$ & $-4.20 *$ & $-4.86^{*}$ & $9.38^{* *}$ & $7.25^{*}$ & $10.87^{* *}$ & $-4.24 *$ & $-4.90 *$ & $0.49 *$ \\
\hline & Peru & $-3.992 *$ & $-3.912 *$ & $-4.00^{*}$ & $-3.92 *$ & $7.92 *$ & $4.76^{* * *}$ & $7.12 * *$ & $-3.92 *$ & $3.88 * *$ & $0.35^{*}$ \\
\hline & Venezuela & $-4.122 *$ & $-4.068 *$ & $-4.14 *$ & $-4.11 *$ & $8.36^{*}$ & $5.41 * *$ & $8.11 * *$ & $-4.23 *$ & $-4.23 *$ & $0.14^{*}$ \\
\hline
\end{tabular}

(Note) 1 . The null hypothesis for the ADF test $\left[t_{\mu}\right.$ and $\left.t_{\tau}\right]$, the DF test $\left[t_{\alpha^{*}}\right.$ and $\left.t_{\alpha^{\sim}} \sim\right]$ and the Phillips-Perron (PP) tests $\left[Z\left(\Phi_{1}\right), Z\left(\Phi_{2}\right), Z\left(\Phi_{3}\right), Z\left(\tau_{\alpha^{*}}\right)\right.$, and $\left.Z\left(\tau_{\alpha^{*}}\right)\right]$ is that the series contain unit roots. For the KPSS test, $\Phi_{1}$ the null hypothesis is that the series is stationary.

2. The statistics $t_{\mu}$ and $t_{\tau}$ in the ADF test, and $t_{\tau}{ }^{*}$ and $t_{\alpha} \sim$ in the DF test respectively include intercept and trend and intercept. The test statistics for PP test are given in detail in Perron (1988, p.308-309).

3. The lag length for the ADF is chosen by minimizing the AIC.

4. *,** \& *** indicate the significance level at the $1 \%, 5 \%$ and $10 \%$ respectively. 


\section{A. Long-term Analysis}

The feasibility of an economic union boils down to the joint behavior of the long-run trends and the short-run responses of economies to internal and external shocks. Hence, we attempt to interpret our empirical findings in line with this spirit. The results of the cointegration tests are presented in Table 3. Both $\lambda_{\text {trace }}$ and $\lambda_{\max }$ statistics ensure the presence of two cointegrating vectors (i.e. $r=2$ ) in real GDP. This means that there exist 5 common trends in the real GDP of these seven countries. The existence of common trends indicates that the real GDP of these countries moves together in the long run. Similarly, the cointegraion results indicate the existence of 4 common stochastic trends (i.e. $r=3$ ) in the trade variables. In fact, the existence of at least one cointegrating vector is required to establish a long run relationship among a set of variables. Thus, this result suggests that trade among these countries cannot swing in the long term but rather that they eventually move together. 
Table 3. Johansen's Cointegration test statistics

\begin{tabular}{|c|c|c|c|c|c|c|c|}
\hline Variables & Eigenvalues & $\mathrm{H}_{0}$ & $\mathrm{H}_{\mathrm{a}}$ & $\lambda$-trace & $\mathrm{H}_{0}$ & $\mathrm{H}_{\mathrm{a}}$ & $\lambda$-max \\
\hline \multirow{7}{*}{$R G D P$} & 0.686 & $r=0$ & $r>0$ & $160.46^{*}$ & $r=0$ & $r=1$ & $54.43 *$ \\
\hline & 0.651 & $r \leq 1$ & $r>1$ & $106.03 *$ & $r=1$ & $r=2$ & $49.50 *$ \\
\hline & 0.454 & $r \leq 2$ & $r>2$ & 56.53 & $r=2$ & $r=3$ & 28.46 \\
\hline & 0.224 & $r \leq 3$ & $r>3$ & 28.06 & $r=3$ & $r=4$ & 11.94 \\
\hline & 0.170 & $r \leq 4$ & $r>4$ & 16.12 & $r=4$ & $r=5$ & 8.81 \\
\hline & 0.122 & $r \leq 5$ & $r>5$ & 7.30 & $r=5$ & $r=6$ & 6.12 \\
\hline & 0.025 & $r \leq 6$ & $r>6$ & 1.19 & $r=6$ & $r=7$ & 1.19 \\
\hline \multirow{7}{*}{ TRADE } & 0.889 & $r \leq 0$ & $r>0$ & $186.48^{*}$ & $r=0$ & $r=1$ & $63.95^{*}$ \\
\hline & 0.792 & $r \leq 1$ & $r>1$ & $122.53 *$ & $r=1$ & $r=2$ & $45.50 *$ \\
\hline & 0.734 & $r \leq 2$ & $r>2$ & $77.03 *$ & $r=2$ & $r=3$ & $38.38^{*}$ \\
\hline & 0.542 & $r \leq 3$ & $r>3$ & 38.65 & $r=3$ & $r=4$ & 22.65 \\
\hline & 0.284 & $r \leq 4$ & $r>4$ & 16.01 & $r=4$ & $r=5$ & 9.69 \\
\hline & 0.184 & $r \leq 5$ & $r>5$ & 6.31 & $r=5$ & $r=6$ & 5.89 \\
\hline & 0.014 & $r \leq 6$ & $r>6$ & 0.42 & $r=6$ & $r=7$ & 0.42 \\
\hline \multirow{7}{*}{ INVEST. } & 0.705 & $r \leq 0$ & $r>0$ & $147.32 *$ & $r=0$ & $r=1$ & $56.13 *$ \\
\hline & 0.495 & $r \leq 1$ & $r>1$ & 91.18 & $r=1$ & $r=2$ & 31.41 \\
\hline & 0.429 & $r \leq 2$ & $r>2$ & 59.78 & $r=2$ & $r=3$ & 25.82 \\
\hline & 0.325 & $r \leq 3$ & $r>3$ & 33.95 & $r=3$ & $r=4$ & 18.12 \\
\hline & 0.196 & $r \leq 4$ & $r>4$ & 15.84 & $r=4$ & $r=5$ & 10.03 \\
\hline & 0.117 & $r \leq 5$ & $r>5$ & 5.81 & $r=5$ & $r=6$ & 5.75 \\
\hline & 0.001 & $r \leq 6$ & $r>6$ & 0.06 & $r=6$ & $r=7$ & 0.06 \\
\hline \multirow{7}{*}{ CONS. } & 0.682 & $r \leq 0$ & $r>0$ & $159.67 *$ & $r=0$ & $r=1$ & $52.78^{*}$ \\
\hline & 0.592 & $r \leq 1$ & $r>1$ & $106.89^{*}$ & $r=1$ & $r=2$ & $41.31 *$ \\
\hline & 0.463 & $r \leq 2$ & $r>2$ & 65.57 & $r=2$ & $r=3$ & 28.65 \\
\hline & 0.346 & $r \leq 3$ & $r>3$ & 36.92 & $r=3$ & $r=4$ & 19.55 \\
\hline & 0.194 & $r \leq 4$ & $r>4$ & 17.36 & $r=4$ & $r=5$ & 9.95 \\
\hline & 0.141 & $r \leq 5$ & $r>5$ & 7.41 & $r=5$ & $r=6$ & 7.02 \\
\hline & 0.008 & $r \leq 6$ & $r>6$ & 0.38 & $r=6$ & $r=7$ & 0.38 \\
\hline
\end{tabular}

(Note) $*$ indicates rejection of the null hypothesis at 5\% significance level.

Cointegration results reveal that both investment and consumption also share 6 and 5 common trends in the long-run, respectively. Several studies (e.g. see Engle and Issler, 1993; Sato and Zhang, 2006; Castillo Ponce and Ramirez-Acosta, 2008) have looked at only the long and short run behavior of GDP to examine the possibility of economic or monetary union. Our analysis of additional macro variables - intra-regional trade, investment, and consumption provide additional evidences for decision makers. The 
existence of common trends suggests that these seven countries may be considered to be candidates for an economic union. We also check whether the residuals of the four variables are serially uncorrelated. The Lagrange multiplier test reveals that we fail to reject the null hypothesis of no serial correlation at the 5\% significance level in each cointegrating model.

The presence of one or more cointegrating vectors necessitates a long run relationship among them, but each variable in the model may not be sufficiently statistically significant to move the system towards long run equilibrium(s). Hence, in order to establish the individual significance of each variable we conduct likelihood ratio (LR) tests for the restrictions that each variable in the cointegrating vector is zero, i.e. $\mathrm{H}_{0}: \beta_{k}=0$ where $k=1,2, \ldots 7$. The significance of the variables is tested in all four models. The LR test statistics are reported in Table 4. The results for individual significance are somewhat mixed. For instance, the real GDP of Peru is not significant at the 5\% level. For investment, Brazil turns out to be insignificant at the 5\% level. In establishing the long run relationship in the consumption pattern of these countries, Colombia is insignificant at the 5\% level. Based on the properties of individual series, the rest of the countries are equally important. Note that none of these countries are consistently insignificant in all four models. Therefore, we opted to proceed with our analysis with all seven countries.

${ }^{7}$ The autocorrelation test results are not reported here. 
Table 4. Likelihood Ratio statistics

(for the significance of individual coefficients in the cointegrating model.)

\begin{tabular}{|c|c|c|c|}
\hline Variable & Country & $\chi_{(2)}^{2}$ & $p$-value \\
\hline \multirow{7}{*}{$R G D P$} & Argentina & 23.18 & 0.00 \\
\hline & Brazil & 18.52 & 0.00 \\
\hline & Chile & 20.36 & 0.00 \\
\hline & Colombia & 13.06 & 0.00 \\
\hline & Mexico & 11.57 & 0.00 \\
\hline & Peru & 4.66 & 0.09 \\
\hline & Venezuela & 20.40 & 0.00 \\
\hline \multirow{7}{*}{ TRADE } & Argentina & 26.17 & 0.00 \\
\hline & Brazil & 28.22 & 0.00 \\
\hline & Chile & 29.02 & 0.00 \\
\hline & Colombia & 16.58 & 0.00 \\
\hline & Mexico & 25.03 & 0.00 \\
\hline & Peru & 36.30 & 0.00 \\
\hline & Venezuela & 13.22 & 0.00 \\
\hline \multirow{7}{*}{ INVEST. } & Argentina & $\begin{array}{r}\chi_{(1)}^{2} \\
15.63\end{array}$ & 0.00 \\
\hline & Brazil & 1.81 & 0.17 \\
\hline & Chile & 17.52 & 0.00 \\
\hline & Colombia & 8.73 & 0.00 \\
\hline & Mexico & 13.65 & 0.00 \\
\hline & Peru & 23.13 & 0.00 \\
\hline & Venezuela & 8.38 & 0.00 \\
\hline \multirow{7}{*}{ CONS. } & Argentina & 17.31 & 0.00 \\
\hline & Brazil & 12.63 & 0.00 \\
\hline & Chile & 8.12 & 0.01 \\
\hline & Colombia & 5.88 & 0.05 \\
\hline & Mexico & 6.73 & 0.03 \\
\hline & Peru & 22.60 & 0.00 \\
\hline & Venezuela & 9.46 & 0.00 \\
\hline
\end{tabular}


The trend components of real GDP are plotted in Figure 1. From the figure, it is apparent that the long term trends are synchronized. The long-run co-movement of real GDP suggests that these countries are reacting to shocks in a similar way in the long run. We can also observe two noticeable characteristics in their trend components. First, Argentine and Venezuelan trend components are highly synchronized throughout the sample period. Second, economic growth in Brazil coincides with economic downturn in Chile and vice versa from 1981 to 1992 . The existence of co-movement in trend behavior (Figure1) suggests that although these economies might have monetary and fiscal policy differences they eventually adjust to the long run common trend and any divergence from the long run equilibrium is short-lived.

\section{Figure 1. The Trend components of Real GDP}

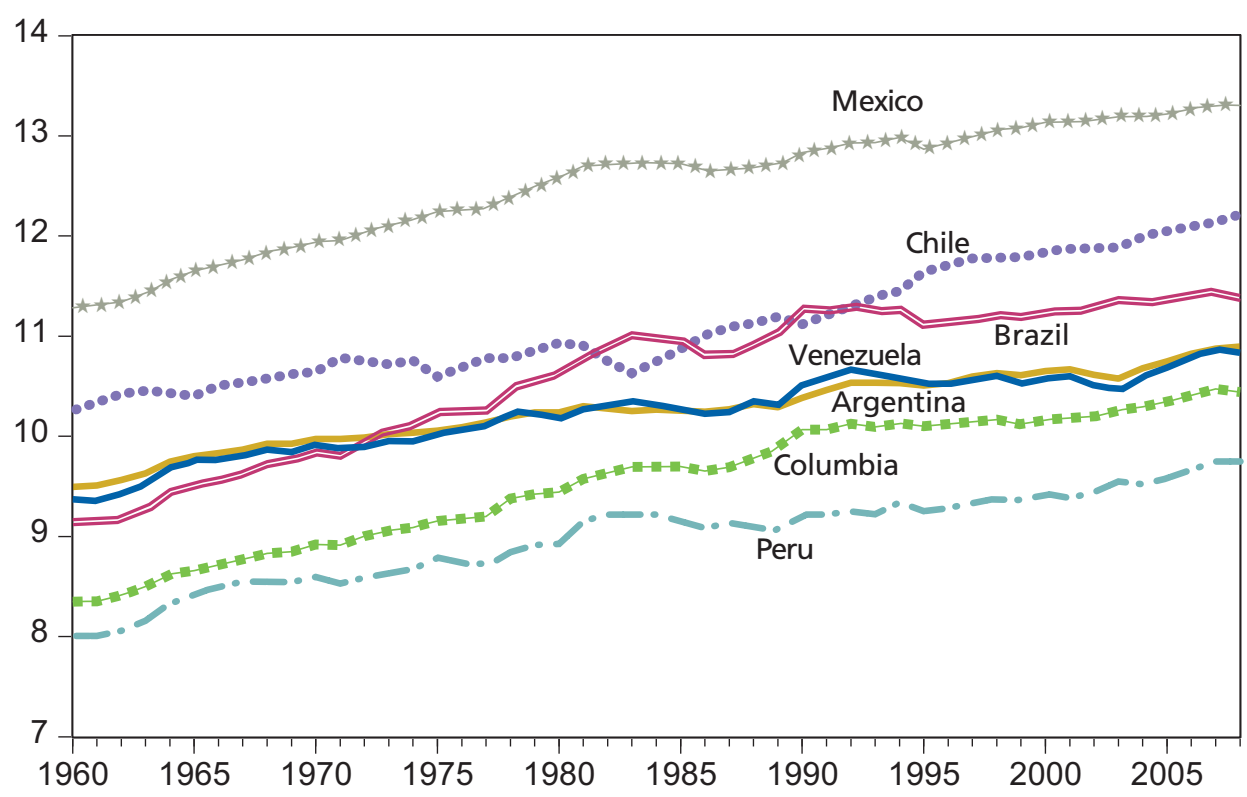


The trend behavior of investment is plotted in Figure 2. Our empirical evidence suggests that, as these economies share at least six common trends, there is not a single source of the common long run movements which can account for the synchronized movement in the investment series. Figure 2 displays the permanent (trend) components of investment in the seven economies. The volatility in trend components is distinct and apparent for all economies under consideration. The long run dynamics are captured by the upward and downward movement of the trend components. This indicates that permanent shocks have played a key role in determining investment decisions. This is also justified by the stylized fact that investment is less likely to react to transitory shocks. The long run behavior of investment reflects the good and bad times these countries have gone through over time. Latin America has a well established history of crises and financial instability appears to have become the norm, rather than the exception (Edwards, 2003). In Figure 2, we can see two notable instances among the trend components of investment during the entire sampling period. First, the volatility in trend components is pronounced in all countries between 1979 and 1983. Second, three countries - Argentina, Chile, and Colombia - have developed a more synchronized investment trend since the late 1980s.

Figure 2. The Trend components of Investment

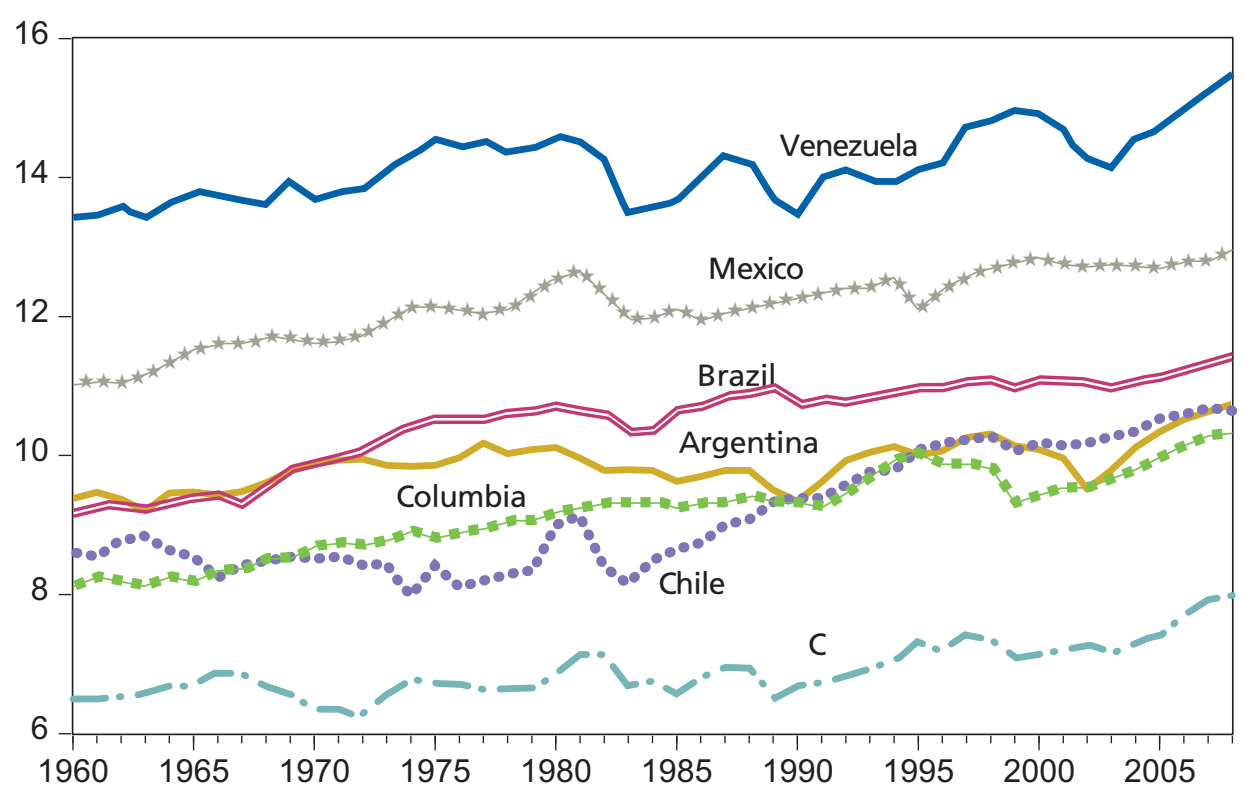


The trend components of consumption are plotted in Figure 3. The trend in the consumption series is synchronized for all seven countries, suggesting that these countries do not have different behavior in the long run. The co-movement in the series is strong and persistent. They demonstrate a high degree of coinciding expansion and contraction during the study period. The volatility of Mexican, Peruvian, and Venezuelan trends clearly stand out from those of other countries. The trend components of Mexico, Venezuela, and Peru are below zero, suggesting that transitory shocks play an important role. The trend for these three economies peaks around 1989 1990 followed by a downturn in their consumption. Nonetheless, co-movement is strong throughout the sampling period.

Figure 3. The Trend components of Consumption

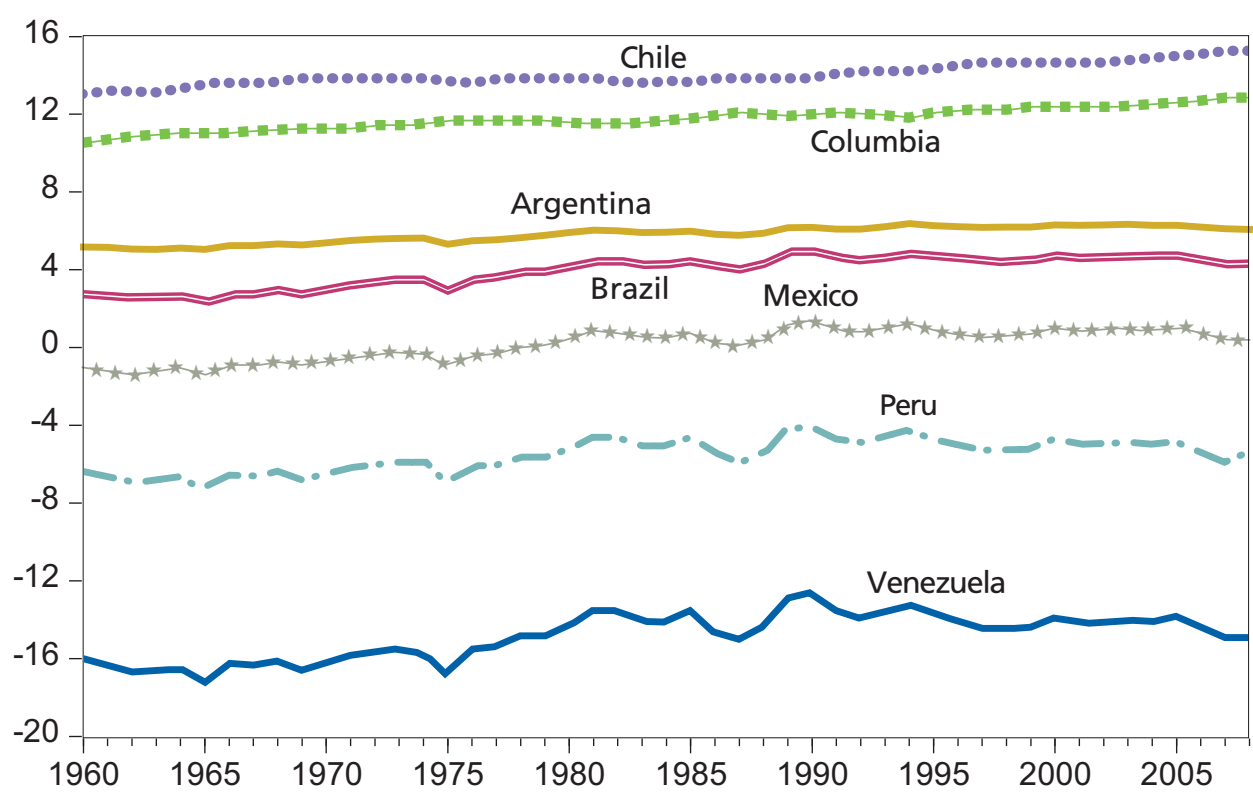

\section{B. Short-term Analysis}

The next step is to determine whether the series have common cycles by testing for the significance of the canonical correlation. Table 5 presents the results of the F-statistics to determine the number of common cycles in a series. Note that cofeature rank $s$ is the number of statistically zero canonical correlations (Engle and Issler, 1993). The results indicate that the cofeature rank for real GDP is 5 (i.e. $s=5$ ). Thus, the 
output of these countries shares two independent cycles and does have similar short-run fluctuations. In this case, we have $r+s=n$ (i.e. $2+5=7$ ) which allows us to perform a special trend-cycle decomposition of a set of seven GDPs.

Table 5. Test statistics for the number of common cycles

\begin{tabular}{|c|c|c|c|}
\hline Variables & $\rho_{i}^{2}$ & $\mathrm{H}_{0}$ & $F$-statistics \\
\hline \multirow{7}{*}{$R G D P$} & 0.03 & $s=1$ & 0.59 \\
\hline & 0.10 & $s=2$ & 0.91 \\
\hline & 0.16 & $s=3$ & 1.02 \\
\hline & 0.23 & $s=4$ & 1.13 \\
\hline & 0.29 & $s=5$ & 1.20 \\
\hline & 0.40 & $s=6$ & $1.36^{*}$ \\
\hline & 0.74 & $s=7$ & $2.17^{*}$ \\
\hline \multirow{7}{*}{$T R A D E$} & 0.02 & $s=1$ & 0.23 \\
\hline & 0.04 & $s=2$ & 0.22 \\
\hline & 0.21 & $s=3$ & 0.50 \\
\hline & 0.30 & $s=4$ & 0.64 \\
\hline & 0.62 & $s=5$ & 1.13 \\
\hline & 0.73 & $s=6$ & $1.57^{*}$ \\
\hline & 0.92 & $s=7$ & $2.60 *$ \\
\hline \multirow{7}{*}{ INVEST. } & 0.06 & $s=1$ & 0.25 \\
\hline & 0.11 & $s=2$ & 0.28 \\
\hline & 0.15 & $s=3$ & 0.31 \\
\hline & 0.25 & $s=4$ & 0.40 \\
\hline & 0.36 & $s=5$ & 0.51 \\
\hline & 0.67 & $s=6$ & 0.84 \\
\hline & 0.80 & $s=7$ & $1.27 *$ \\
\hline \multirow{7}{*}{ CONS. } & 0.00 & $s=1$ & 0.09 \\
\hline & 0.01 & $s=2$ & 0.11 \\
\hline & 0.05 & $s=3$ & 0.22 \\
\hline & 0.27 & $s=4$ & 0.74 \\
\hline & 0.38 & $s=5$ & 1.12 \\
\hline & 0.51 & $s=6$ & $1.51^{*}$ \\
\hline & 0.71 & $s=7$ & $2.19^{*}$ \\
\hline
\end{tabular}

(Note) *indicates rejection of the null hypothesis at the $10 \%$ significance level.

$\rho_{i}^{2}$ is the squared canonical correlation. 
The null hypothesis that the cofeature space has a dimension of seven is rejected for the rest of the three variables - trade, investment, and consumption. The cofeature rank for trade is 5 (i.e. $s=5$ ). This implies that these countries share two common cycles in their trade pattern. We further note that for investment $s=6$, suggesting at least one common cycle. Finally, at the 5\% significance level the F-test confirms that for consumption $s=5$. This suggests that the system of seven Latin American consumption series possesses two common cycles. The special condition i.e. $r+s=n$ is not satisfied for the trade variable. However, for investment and consumption, the number of cointegrating vectors $(r)$ and cofeature vectors $(s)$ add up to the number of the total variables $(n)$. Therefore, we can decompose three out of the four variables into their trend and cyclical components.

The cyclical behaviors of real GDP, investment, and consumption are plotted in Figures 4, 5, and 6, respectively. One striking point of the cyclical components of real GDP is that Argentina, Brazil, Colombia, Peru, and Venezuela move together during the entire sample period. Moreover, their cyclical components display similar and comparable turning points. The duration, intensity, and persistence of the movements are the most visible characteristics of the cyclical components. The synchronous shortterm and long-term behavior of output is considered key to forming an economic union (Beine, Candelon, and Hecq, 2000).

Figure 4. The Cyclical components of Real GDP

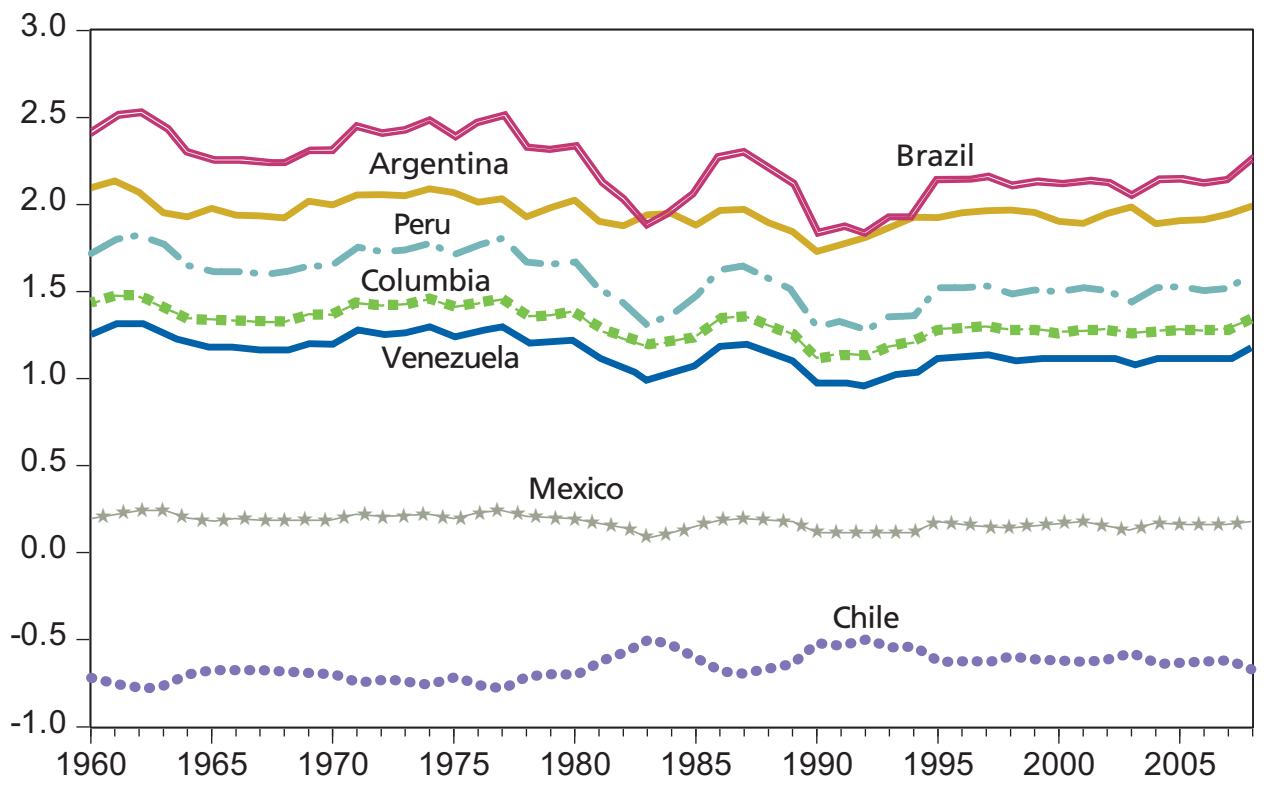


From Figure 4 we further observe that while the Mexican cycle is quite stable during the entire sample period, Chile is inversely related to the rest of the economies. One possible reason for this inverse relationship could be Chile's recent obsession with bilateral regional agreements (Hosono and Nishijima, 2003). Chile is regarded as the most liberalized country in the region. In pursuit of trade liberalization, Chile has even adopted a uniform tariff rate policy, assuring its trading partners that no sector is preferential or protected. Given the speed of this openness, it is plausible that the sources of shocks are numerous and that their transmission channels to Chile might be different than that of the other countries. Additionally, several changes took place in Chile in the 1970s and 1980s that did not necessarily coincide with those of other countries in the region. When the military took power in September 1973, Chile accelerated trade and financial liberalization policies. The government adopted a flat 10 percent tariff in addition to price deregulation and exchange rate devaluations as a part of long term structural transformation. This course, however took a reversal course in the 1980s. The country experienced a severe recession in the early 1980s, leading a soaring unemployment rate of $26.4 \%$. At the same time, private sector indebtedness grew from 42 percent to 70 percent of GDP between 1980 and 1982. All these events put pressures on the government to reverse the liberalization process (for details please see Schamis, 1999). These factors can be attributed to the inverse behavior of Chile. The relatively smooth cyclical components of Mexico shed some lights on its macroeconomic fundamentals. First, they indicate that the transmission of shocks from the rest of the countries to the Mexican economy is negligible and second, its macroeconomic interdependence with more stable economies of the US and Canada is strong. The intraregional trade share of Mexico is around 5\% whereas the intra-regional trade of rest of the countries account for up to $42 \%$ of total trade on average (see Table 1) during the sample period. Mexico has stronger trade ties with its fellow NAFTA members. The cyclical component of Chile is below zero, suggesting that its output remained below its trends during this period. 
Figure 5. The Cyclical components of Investment

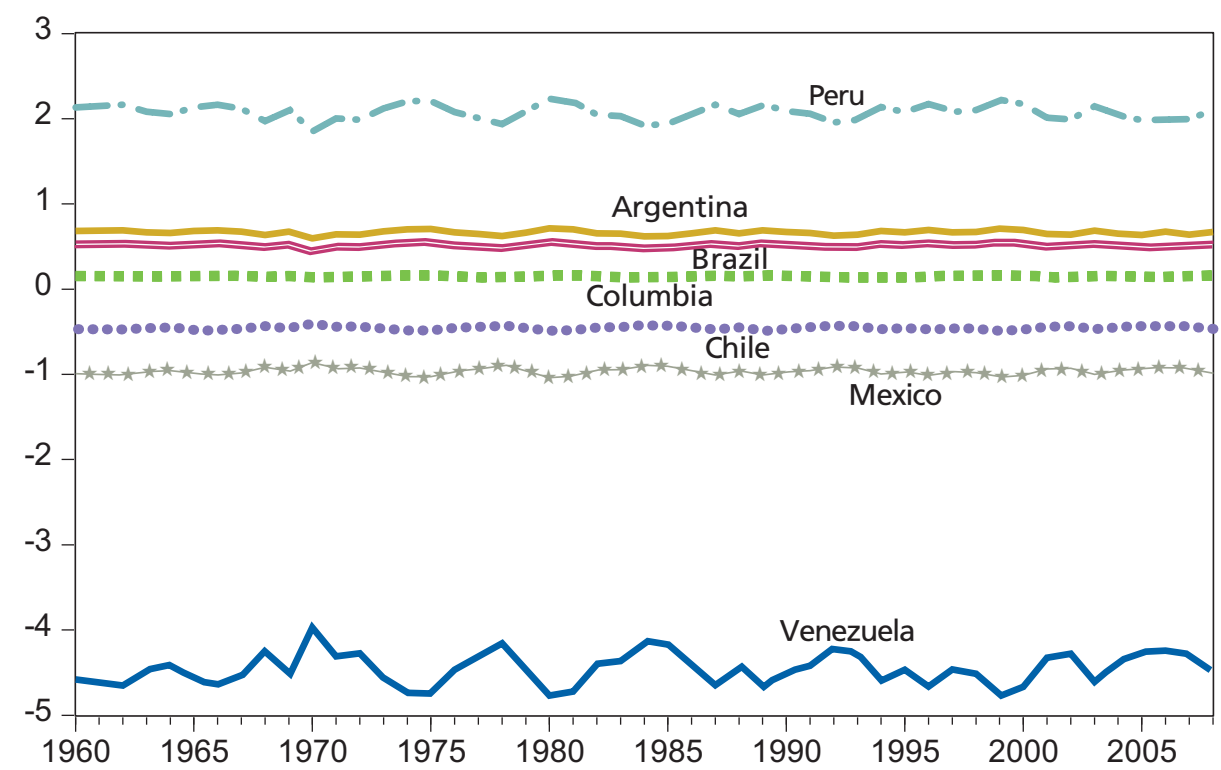

In Figure 5, we plot the short-run fluctuations in investment series. Transitory movements in investment have one cycle in common (see Table 5). The cyclical components of these series exhibit strong co-movement. Indeed, the co-movement of four countries-Argentina, Brazil, Chile, and Colombia - are very similar and the transitory components are positive. In contrast, the cyclical movements of Chile, Mexico, and Venezuela do not resemble those of the four other countries. They share strong comovement among themselves and their transitory components are negative (Figure 4) resulting in negative correlation with the rest of the countries. Engle and Issler (1993) point out that the comovement of responses depends on, among other factors, the speed of adjustments and the adjustment between countries varies from time to time, and may even have reversals at times, but eventually the countries achieve a new equilibrium. This result suggests that, although these economies will converge to a common trend in the long term, they opt to employ different policy requirements in the short run to adjust their economies to cyclical fluctuations. Therefore, this result may imply that these three countries require different policy tools to stabilize their short-run fluctuations. 
Figure 6. The Cyclical components of Consumption

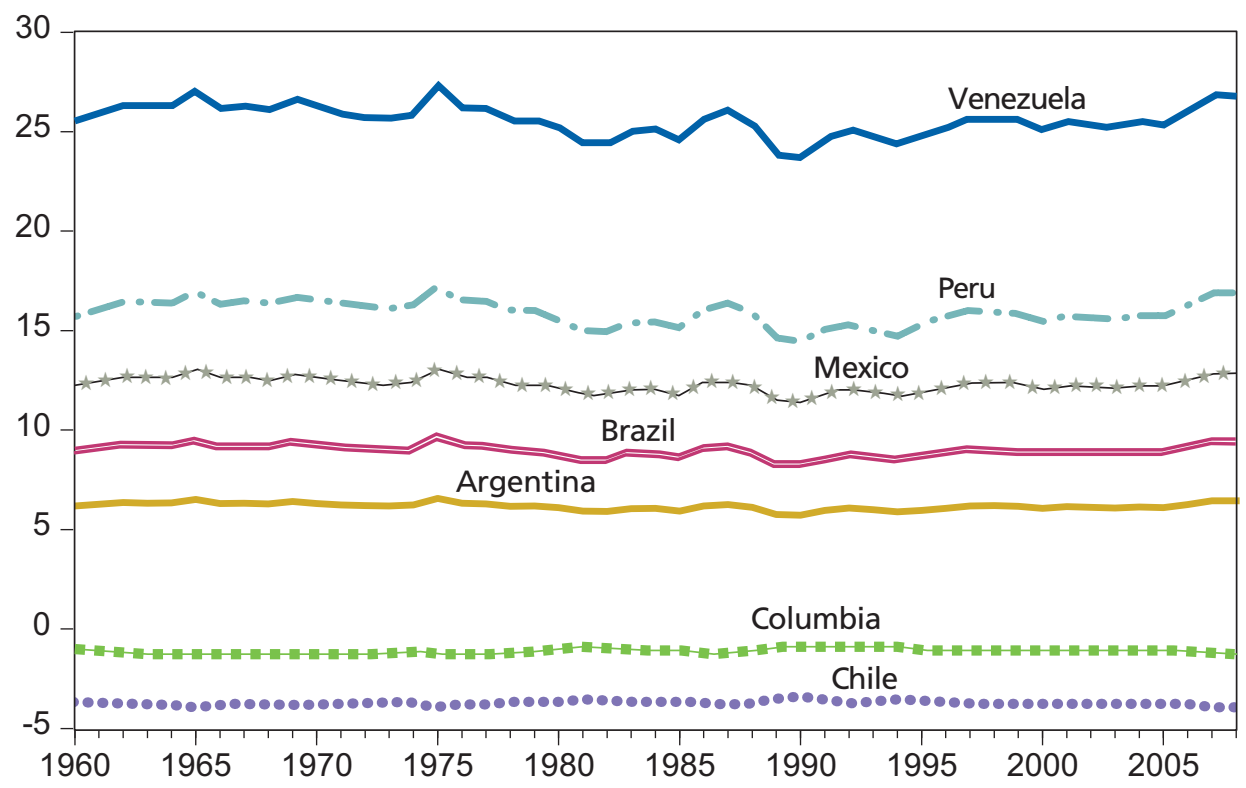

Further, we can also observe a strong co-movement in the cyclical components of consumption. The cyclical components in Figure 6 exhibit strong synchronous movements throughout the sampling period. One striking characteristic of the cyclical components of consumption is that their cyclical movement is strikingly similar to the cyclical movement of real GDP (Figure 4). This result, however, is not surprising because the consumption of a country is very likely to follow the dynamics of the real output of the country. Second, these are the largest and leading economies with several things in common such as language with the exception of Brazil, cultural, degree of openness, etc.

\section{Economic Integration Analysis}

Following Balassa (1961), regional economic integration is defined as a process of eliminating various forms of discrimination between national economies. Economic integration can be reflected in substantial flows of goods and services and synchronous responses of economic variables to internal and external disturbances. Mundell (1961) characterizes the integration of product and factor markets as crucial factors 
for adopting the optimum currency. Additionally, Mundell also highlights the nature of shocks (whether symmetric or asymmetric) and their impact on economies. Other researchers such as Mckinnon (1963) and Kenen (1969) point out the size of economies, the similarity of economic structures between countries, the level of fiscal integration, etc. as important factors to consider prior to forming an economic union. However, in the recent decades much of the literature (e.g. Mills and Holmes, 1999; Beine et. al., 2000; Bayoumi, Eichengreen, and Mauro, 2000; Sato and Zhang, 2006; CastilloPonce and Ramirez-Acosta, 2008; Abu-Qarn and Abu-Bader 2008; Adom et al. 2010 among others), in addition to the above mentioned criteria, focus on the long run and short run behavior of economies. The implication of this relationship is that countries experiencing asymmetric disturbances are poor candidates for forming an economic union (Bayoumi and Eichengreen, 1994).

When a group of variables that apply to several economies moves together over time, this movement can be caused by economic linkages among these economies. Similarly, highly correlated business cycles are also considered to be a pre-condition for a suitable economic union. Having identified shared common trends and common cycles in the output of NAFTA member countries, Castillo-Ponce and Ramirez-Acosta (2008) note the possibility of a deeper economic association or even a monetary union among them. Following the preconditions regarding economic union available in the literature, Adom et al. (2010) propose: "for a group of countries to form a meaningful economic union, it is sufficient to have synchronous long term movements in their GDPs and some other macro-variables, but it is necessary to have short-run business cycles (common-features) in their GDPs and some other macro-variables" (page 248). Thus the implication of long-term trends and short term cycles for economic union has been supported in the existing literature.

Cointegration analysis identifies the common trends that tie the variables together in the long run. The common feature test presents the evidence of common business cycles in the short run. Common trends are viewed in the context of long run relationships between variables; common cycles, on the other hand, are viewed as the short run phenomenon of shocks to an economy and their effects in the short run. On the empirical side, earlier researchers followed the Blanchard and Quah (1989) methodology on the bivariate basis to investigate the degree of symmetry/asymmetry of shocks. Such an approach suffers from several shortcomings, most notably it does not distinguish between the stochastic trends and common cycles in a series (see e.g. Beine et al., 2000, Sato and Zhang, 2006, and Adom et al., 2010). The analysis of common 
trends and common cycles provides adequate evidence about the stance and course of macroeconomic convergence (Weber, 2006). The presence of such a common trend in a set of variables is associated with the long run structural and institutional characteristics of the country under consideration (Mills and Holmes, 1999). The presence of common cycles is evidence that output variability across countries depends upon the same kind of shocks.

In this study, we examined the feasibility of an economic union in Latin America by pursuing the idea that a complete picture of integration can be sketched by knowing both the long-run and short-run phenomenon of the economies in question. The main concern of countries striving for an economic union is whether or not their output fluctuations are synchronous in the long run as well as in the short run. Upon analyzing the preconditions for a viable economic union outlined in the literature, a simple question is: to what extent do the economic conditions that prevail in the Latin American countries encourage the formation of an economic union? We note that the trend components of real GDP in these countries share a strong positive relationship, i.e. they follow the same direction. The cyclical components seem to be producing the same rhythm except for Brazil, which seems relatively more volatile. This can partly be explained by the series of financial crises that took place in Brazil. One interesting point to make in the trend-cycle decomposition is that both Mexico and Argentina suffer from financial crisis in 1994 and 2001, respectively, but these crises did not create noticeable short-term volatility in their output. Our empirical findings indicate that the investment and consumption of Latin American countries share synchronous behavior both in the long run and the short run. Moreover, such synchronous behavior of macro variables depends upon both the correlation of shocks and the similarity of the responses to shocks (Engle and Issler, 1993).

\section{Conclusion}

This paper explores the feasibility of an economic union among seven leading economies in Latin America - Argentina, Brazil, Chile, Colombia, Mexico, Peru, and Venezuela - by analyzing the long term and short term relationships among key macro variables, i.e. real GDP, intra-regional trade, private investment, and consumption. The results indicate that the macro variables of these countries move towards a common 
trend in the long run and are subject to synchronous cycles in the short run. This result suggests that these economies appear to be a core group in the region in that they have common shocks and react to those shocks in a similar fashion. Thus, the policy makers of these countries can initiate an economic union as the macroeconomic conditions are favorable for them to do so.

The key finding from trend-cycle decomposition is that the two important preconditions - long run comovement and short run synchronous fluctuations in economic indicators - for an economic union have been extracted. We found that all four macro variables, i.e. real GDP, intra-regional trade, private investment, and consumption move to common trend in the long run and share common cycles in short run fluctuations. Since the long run and short run movements of macro variables follow a similar pattern in terms of the impact of duration, intensity, and timing the results suggest that these countries face symmetric shocks that warrant similar policy responses. This study further highlights that none of the countries except Chile show persistent dissimilarities in all macroeconomic variables investigated. They rather show synchronous long term and short term behavior. Chile's asynchronous response might not be an impediment to greater unity, especially given its size and role. After all, economic integration is largely dependent upon political cooperation. To some extent, we do not pretend to provide an exhaustive assessment. Additionally, this paper does not quantify the interdependency of the labor market. Therefore, the entirety of our findings should be taken cautiously. Nonetheless, overwhelming evidence indicates, among others, two policy implications. First, since their macro economies are synchronized it would not be especially costly to form an economic union in the region. Second, the existence of macroeconomic synchronization gives rise to further debate on whether Latin America is ready for a common currency.

Received 31 January 2013, Revised 09 April 2013, Accepted 03 June 2013

\section{References}

Abu-Qarn, Aamer S., and Suleiman Abu-Bader (2008), On the optimality of a GCC Monetary Union: structural VAR, common trends, and common cycles evidence, The World Economy, 31, 612-630.

Adom, A.D. et al. (2010), Economic Integration in Africa, The Quarterly Review of Economcis and Finance, $50,245-253$.

Allegret, Jean-Peirre, and Sand-zantman Alain (2009), Does a monetary union proect against external shock? 
An assessment of Latin American integration, Journal of Policy Modeling, 31, 102-118.

Arnaudo, Aldo A. and Alejandro D Jacobo (1997), Macroeconomic homogeneity within Mercosur: An overview, Estudios Economicos, 12, 37-51.

Balassa, Bela (1961), The Theory of Economic Integration, Irwin, Homewood.

Beine, Michel, Bertrand Candelon, and Alain Hecq (2000), Assessing a Perfect European Optimum Currency Area: A common Cycles Approach, Empirica, 27, 115-132.

Bayoumi, Tamim, and Barry Eichengree (1994), One Money or many? Analyzing the prospects for monetary unification in various parts of the world, Princeton Studies in International Finance, No. 76.

Bayoumi, Tamim, Barry Eichengreen, and Paolo Mauro (2000), On regional monetary arrangements for ASEAN, Journal of the Japanese and International Economies, 14, 121-148.

Berg, Andrew, Eduardo Borensztein, and Paolo Mauro (2002), An evaluation of monetary regime options for Latin America, IMF working paper, wp/02/211.

Blanchard, Olivier J., and Danny Quah (1989), The dynamics effects of Aggregate demand and supply disturbances, American Economic Review, 79, 655-673.

Bond, Robert J. 1978. Regionalism in Latin America: prospects for the Latin American Economic System (SELA), International Organization, 32, 401-423.

Castillo Ponce, Ramon A., and Ramon De Ramirez Acosta (2008), Economic Integration in North America, Applied Econometrics and International Development, 8, 111-122.

Caceres, Luis R. (2011), Economic Integration and Unemployment in Mercosur, Journal of Economic Integration, $26,45-65$.

Chiquiar, Daniel, and Romas-Francia (2005), Trade and business-cycle synchronization: evidence from Mexican and U.S. manufacturing industries, the North American Journal of Economics and Finance, 16, 187216.

Christodoulakis, Nicos, and Sophia P. Dimelis (1995), Comparisions of business cycles in the EC: Idiosyncrasies and Regularities, Economica, 62, 1-27.

De Grauwe, Paul, and Zhaoyong Zhang (2006), Intruduction: Monetary and Economic Integration in the East Asian Region, The World Economy, 29, 1643-47.

Dickey, David A., and Wayne A. Fuller (1979), Distribution of the estimators for autoregressive time series with a unit root, Journal of American Statistical Association,74, 427-431.

Dickey, David A., and Wayne A. Fuller (1981), Likelihood ratio statistics for autoregressive time series with a unit root, Econometrica, 49, 1057-1072.

Edwards, Sebastain (2003), Financial instability in Latin America, Journal of International Money and Finance, 22, 1095-1106.

Engle, Robert, and Joao V. Issler (1993), Common trends and common cycles in Latin America, Revista Brasileira de Economica, 47, 149-76.

Fiess, Norbert (2007), Business cycle synchronization and regional integration: a case study for Central America, The World Bank Economic Review, 21, 49-72.

Fiorito, Riccardo, and Tryphon Kollintzas (1994), Stylized facts of Business Cycles in the G7 from a real 
business cycle perspective, European Economic Review, 38, 235-269.

Fullerton, Thomas M., and Eiichi Araki (1996), New directions in Latin American macroeconometrics, Economic and Business Review, 38, 49-73.

Hallwood, Paul, Ian W. Marsh, and Jorg Scheibe (2006), An assessment of the case for monetary union or official dollarization in five Latin American countries, Emerging Markets Review, 7, 52-66.

Hernandez, Jorge H (2004), Business cycles in Mexico and the United States: do they share common movements?, Journal of Applied Economies, VII, 303-323.

Hosono, Akio, and Shoji Nishijima (2003), Prospects for Closer Economic Relations between Latin America and Asia, RIEB discussion paper series No.121.

International Monetary Fund, Direction of Trade Statistics Yearbook, Various Issues.

Jacobo, Alejandro D. (2002), Taking the business cycle's pulse to some Latin American Economies: is there a rhythmical beat?, Estudios Economicos, 29, 219-245.

Johansen, Soren. (1988), Statistical analysis of cointegrating vectors, Journal of Economic Dynamics and Control, 12, 231-254.

Johansen, Soren, and Katarina Juselius (1990), Maximum Likelihood estimation and inference on cointegration with application to the demand for Money, Oxford Bulletin of Economics and Statistics, 52, 169-210.

Kenen, Peter B. (1969), The theory of optimum currency areas: an eclectic view. In: Mundell, R., Swoboda, A. (Eds.), Monetary Problems of the International Economy. University of Chicago Press, Chicago, 41-60.

Kwiatkowski, Denis, Peter C.B. Phillips, Peter Schmidt, and Yongcheol Shin (1992), Testing the null hypothesis of stationary against the alternative of a unit root, Journal of Econometrics, 54, 159-178.

McKinnon, Ronald I. (1993), Communications: Optimum currency Area, American Economic Review, 53, 657665 .

Mejia-Reyes, Pablo (1999), Classical business cycles in Latin America: turning points, asymmetries and international synchronization, Estudios Economicos, 14, 265-297.

Mena, Hugo (1995), Pushing the sisyphean Boulder? Macroeconometrics testing in Latin American countries." Review of Income and Wealth, 10, 81-99.

Mills, Terence C., and Mark J. Holmes (1999), Common trends and cycles in European industrial production: exchange rate regimes and economic convergence, The Manchester School, 67, 557-587.

Mundell, Robert A. (1961), A theory of optimum currency areas, The American Economic Review, 51, 657665 .

Phillips, Peter, and Pierre Perron (1988), Testing for a unit root in time series regression, Biometrika, 75, 335346.

Perron, Peirre (1988), Trends and random walks in macroeconomic time series: further evidence from a new approach, Journal of Economic Dynamics and Control, 12, 297-332.

Rao, C. Radhakrishna (1973), Linear Statistical Inference, New York, Wiley.

Rosenthal, Gert (1985), The lessons of economic integration in Latin America; the case of Central America, Westview Press, London, 139-158.

Sato, Kiyotaka, and Zhaoyong Zhang (2006), Real output co-movements in East Asia: Any evidence for a 
Monetary Union?, The World Economy, 29, 1671-1689.

Sato, Kiyotaka, David Allen, and Zhaoyong Zhang (2007), A monetary Union in East Asia: What does the common cycles approach tell?, proceeding of International Congress on Modeling and Simulation, Christchurch, New Zealand.

Schamis, Hector E. (1999), Distributional Coalitions and the politics of Economic Reform in Latin America, World Politics, 51, 236-268.

Schiff, Maurice, and Alan Winters (1998), Regional Integration as diplomacy, World Bank Economic Review, 12, 271-295.

Sharma, Subhash C. (1997), Macroeconomic interdependence and integration in the Indian sub-continent, Journal of quantitative economics, 13, 37-59.

Sylwester, Kevin (2005), Foreign direct investment, growth and income inequality in less developed countries, International Review of Applied Economics, 19, 289-300.

Vahid, Farshid, and Robert F. Engle (1993), Common trends and common cycles, Journal of Applied Econometrics, 8, 341-360.

Weber, Enzo. (2006), Macroeconomic integration in Asia pacific: common stochastic trends and business cycle coherence, SFB 649, Discussion Paper, Humboldt University, Berlin, Germany.

World Development Indicators (2009), World Bank. 